\title{
The EU in Kosovo: Operational Dilemmas, Political Priorities and the Realities of Post-Conflict Assistance
}

\author{
MARY VENNER \\ University of New South Wales \\ mary.venner@yahoo.com
}

\begin{abstract}
mailto:mary.venner@yahoo.com
\section{Abstract}

The European Union was a major participant in post conflict reconstruction in Kosovo and continues to be the leading international actor. This article examines the effectiveness of the EU's contribution to developing Kosovo's government institutions and the implementation of its development assistance programs. The EU faced practical difficulties at the very start of its engagement which undermined its impact, and there are ongoing deficiencies in the EU's approach to development assistance. There are also questions about the appropriateness of the EU's strategy in Kosovo from the perspective of Kosovo's economic development. It is argued that EU assistance activities, based on the accession process and compliance with 'European standards,' are excessively complex, are oriented more towards benefiting the EU and its members, and may not address the development problems of Kosovo, or agree with the priorities of Kosovo's population.
\end{abstract}

Keywords: development assistance, European Agency for Reconstruction (EAR), European Union, institution building, Kosovo, UNMIK

\section{Introduction}

The conflict in Kosovo has been identified as a turning point in European Union (EU) foreign policy and its relations with the region. ${ }^{1}$ The change in approach produced the Stability Pact and the Stabilization and Association Process (SAP) and led to the European Commission's decision to take a high profile role in the post conflict reconstruction program in Kosovo. The EU was responsible for one of the four 'pillars' of the UN Mission in Kosovo (UNMIK) and was the largest donor of reconstruction and development assistance. Research on the role of the EU in Kosovo, and in the Western Balkans more broadly, has been generally pessimistic about the effectiveness of the EU as an international actor in these contexts. EU strategy in the region has been variously described as "ungenerous, late and confusing,"2 "disjointed and haphazard,"3 and "plagued with inconsistencies and half-

\footnotetext{
${ }^{1}$ W. Koeth, 'State Building without a State: The EU's Dilemma in Defining its Relations with Kosovo', European Foreign Affairs Review, Vol. 15, No. 2, 2010, pp. 227-247; D. Papadimitriou, 'The EU's Strategy in the PostCommunist Balkans,' Southeast European and Black Sea Studies, Vol. 1, No. 3, 2001, pp. 69-94; A. Shepherd, “'A Milestone in the History of the EU”: Kosovo and the EU's International Role,' International Affairs, Vol. 85, No. 3, 2009, pp. 513-530.

2 Papadimitriou, op. cit., p 79.

3 F. Bieber, 'Building Impossible States? State-Building Strategies and EU Membership in the Western Balkans,' Europe-Asia Studies, Vol. 63, No. 10, 2011, pp. 1783-1802, p. 1785.
} 
baked measures." 4 The idea of EU 'actorness,' or lack thereof, has been raised in this debate. 5 A number of authors have argued that the EU's ability to behave as a credible international actor in Kosovo is undermined by a lack of coordination and coherence in policy development, the multiplicity of EU presences on the ground, the need to share influence with other significant international actors including the UN, NATO and the United States, and differing views of EU member states on the question of Kosovo's independence. ${ }^{6}$ In particular, questions have been raised about the effectiveness and appropriateness of the EU's conditionality policies in Kosovo. A number of factors appear to undermine the EU's strategy in Kosovo. Stabilisation and Association Agreements (SAAs) are less committed to future accession than the 'European Agreements' reached with previous membership applicants in Eastern Europe, ${ }^{7}$ and in any case there is as yet no SAA agreement with Kosovo, ${ }^{8}$ and some of the expected benefits of engagement with the EU, in particular visa liberalisation, are yet to be delivered. 9 The most significant question mark over the prospect of EU membership, however, is the fact that not all EU members have yet recognised Kosovo's declaration of independence.

This article is concerned with the effectiveness of the EU's support for institutional development in Kosovo in the post conflict period and argues that, in addition to the challenges noted above, the EU has been hampered by operational difficulties and inappropriate policies. The analysis focuses primarily on the activities of the EU component of UNMIK and the development assistance activities of the European Agency for Reconstruction (EAR) and, subsequently, the European Commission Liaison Office (ECLO) during the period since 1999. ${ }^{10}$ While Kosovo has made significant progress in developing government functions since the end of the conflict, to which the EU has made a major contribution, the EU's efforts were adversely affected by operational failures early in the history of its involvement, and inefficiencies in the management of EU assistance programs continue to limit the impact of the EU's investments. Furthermore, it can be argued that the policy

\footnotetext{
${ }^{4}$ M.Klasnja, 'The EU and Kosovo: Time to Rethink the Enlargement and Integration Policy?,' Problems of Post Communism, Vol. 54, No. 4, 2007, pp. 15-32, p. 16.

5 L. Greiçevci, 'EU Actorness in International Affairs: The Case of EULEX Mission in Kosovo,' Perspectives on European Politics and Society, Vol. 12, No. 3, 2011, pp. 283-303; S. Harnisch and B. Stahl, 'Fractured Actorness and Its Unintended Consequences: The EU's Kosovo Policy,' contribution to the conference The European Union in International Affairs II, Brussels, 22-24 April 2010, <http://www.ies.be/files/Harnisch-Stahl-E5.pdf>, accessed 20 April, 2011; D. Papadimitriou, P. Petrov, and L. Greiçevci, 'To Build a State: Europeanization, EU Actorness and State-Building in Kosovo,' European Foreign Affairs Review, Vol. 12, No.2, 2007, pp. 219-238. ${ }^{6}$ C. Pippan, 'The Rocky Road to Europe: The EU's Stabilisation and Association Process for the Western Balkans and the Principle of Conditionality,' European Foreign Affairs Review, Vol. 9, No.2, 2004, pp. 219-245; Koeth, op. cit.; Shepherd, op. cit.; Bieber, op. cit.; Harnisch and Stahl, op. cit.; Greiçevci, op. cit.; Klasnja, op. cit.; Papadimitriou, op. cit.; Papadimitriou et al., op. cit.

7 Klasnja, op. cit.; Pippan, op. cit.

${ }^{8}$ Kosovo is the only Western Balkans country without such an agreement however in March 2012 the Enlargement Commissioner announced a feasibility study of the issue of an SAA for Kosovo (BalkanInsight, 'EU Launches Kosovo Feasibility Study,' 27 March 2012, <http://www.balkaninsight.com /en/article/eu-launchesfeasibility-study-with-kosovo $>$, accessed 24 April 2012).

9 In January 2012 the European Commission announced the long awaited start of a 'dialogue' with Kosovo on visa liberalisation (BalkanInsight, 'EU Launches Kosovo Visa Liberalisation Dialogue', 19 January 2012,

<http://www.balkaninsight.com/en/article/ec-kosovo-launches-visa-liberalization-dialogue>, accessed 24 April 2012).

10 The paper draws on a larger research project on the effectiveness of international efforts to establish public administration institutions in Kosovo, focusing on the period from 1999 to 2010. The research sources include reports, policy documents, project descriptions and evaluations produced by organisations involved in Kosovo over the period, and information provided in approximately 40 interviews with international technical advisers, staff of donor organisations, and Kosovo government officials, mostly conducted during fieldwork in Pristina in September and October 2010. All interviewees were promised anonymity and therefore only but non identifying information on their role in Kosovo has been is provided.
} 
priorities and assistance programs that have been pursued through EU mechanisms are excessively complex, are weighted towards benefiting the EU membership and do not necessarily address Kosovo's economic development needs.

\section{The EU and Kosovo since 1999}

Within UNMIK, the EU had responsibility for managing the 'reconstruction' component of the mission, known as Pillar IV, which included the development of government finance functions, the management of public utilities and the privatization of state owned enterprises. A separate body, the European Agency for Reconstruction (EAR), was established to administer EU-funded rebuilding projects. The UN mission was expected to establish and oversee autonomous institutions of self government pending an international agreement on the final status of the territory. No final agreement has yet been achieved however and the UN is still nominally in charge in Kosovo. In February 2008, the elected provisional government unilaterally declared independence and was immediately recognized by the United States and several significant European nations. By June 2012, while 91 countries had formally accepted Kosovo's independence, not all members of the UN Security Council, or five members of the EU had done so. ${ }^{11}$ Following the declaration of independence, both Pillar IV and EAR were closed down and the EU launched a new Law and Justice Mission (EULEX), with responsibility for overseeing police, justice and customs, despite the fact that the UN still technically retains responsibility for these functions under Security Council Resolution 1244. ${ }^{12}$ Responsibility for the program of development projects formerly administered by EAR was passed to the European Commission Liaison Office (ECLO). ${ }^{13}$ The situation in Kosovo is continually evolving and, following entry into force of the Lisbon Treaty, the EU has again reconfigured its representation. Since late 2011, ECLO and the EU Special Representative's office have jointly become the European Union Office in Kosovo. Between 1999 and 2010 the EU spent at least $€ 2.5$ billion in Kosovo through its various agencies. Table 1 shows the major avenues of funding provided by the EU in this period.

Table 1: Estimated Total EU Support to Kosovo 1999-2010 ${ }^{14}$

\begin{tabular}{|l|l|}
\hline & $€$ million \\
\hline CARDS and other EC support (EAR) & 1,249 \\
\hline Support to UNMIK Pillar IV & 136 \\
\hline $\begin{array}{l}\text { Exceptional financial assistance (including budgetary } \\
\text { support) }\end{array}$ & 117 \\
\hline Humanitarian assistance (for the period 1999-2002) & 443 \\
\hline Instrument of Pre Accession (IPA) funds 2008-2010 & 258 \\
\hline EULEX Rule of Law mission, 2009-2010 & 330 \\
\hline Total funding & 2,533 \\
\hline
\end{tabular}

\footnotetext{
${ }^{11}$ Cyprus, Greece, Romania, Slovakia, and Spain have not recognized Kosovo's independence:

<http://www.president-ksgov.net/?page=2,54> , accessed 28 June 2012.

$12<$ http://www.eulex-kosovo.eu/>, accessed 5 May, 2012.

$13<$ http://eeas.europa.eu/delegations/kosovo/index_en.htm>, accessed 9 November, 2011.

14 European Commission, Multi-annual Indicative Planning Document for Kosovo 2008-2010, 2008; EULEX,

'Basic Facts', <http://www.eulex-kosovo.eu/docs/info/basic/Basic-ENG.jpg>, accessed 5 May 2012.
} 


\section{EU operational performance}

From the start of its post conflict engagement in Kosovo, the EU experienced immediate limits on its ability to fulfil its aspirations. Bureaucracy, delay and inadequate resources are a recurring theme in accounts of many EU activities in Kosovo demonstrating a gap between intentions and institutional capacity to deliver. Although many of the initial difficulties have been overcome, criticisms of operational aspects of EU activities in Kosovo continue.

\section{The EU in UNMIK Pillar IV}

The early phases of the establishment of Pillar IV, the EU component of the UN mission, were particularly challenging. The EU lobbied strongly for involvement in the mission ${ }^{15}$ and was assigned responsibility for rebuilding "physical, economic and social infrastructure and systems."16 However, although a handful of senior EU staff arrived in Kosovo very promptly and, at a donors conference in July 1999, announced the EU's plans for institution building and economic development, ${ }^{17}$ the EU found itself unable to provide sufficient financial resources or to identify the technical staff needed for economic reconstruction activities within a reasonable timeframe. ${ }^{18}$ In the weeks immediately after the end of the conflict there was growing concern that delays in establishing the basic functions of public finance management threatened to undermine the reconstruction mission and, according to most sources, it was largely for this reason that the US government became heavily involved in Pillar IV activities. ${ }^{19}$ The US Agency for International Development (USAID) responded quickly and contracted a consulting firm to provide technical advisers able to start work immediately. Thus, the majority of the international experts working in the EU component of UNMIK in the first years of the mission were in fact not appointed or paid by the EU but were engaged on behalf of USAID. This generated a certain amount of conflict within Pillar IV over policy directions, particularly in relation to the privatization of former state owned enterprises..$^{20}$ Many staff had multiple and sometimes conflicting reporting obligations to the UN, the EU and to USAID. ${ }^{21}$ It also made it possible for both the EU and USAID to claim credit for many of Pillar IV's achievements and thus enhanced the already positive views of the US held by the local population. Nine months into the mission, the EU had still only filled 13 positions in Pillar IV, ${ }^{22}$ however by 2005 it had 120 international EU staff, a further 280 local employees and an annual budget of $€ 20$ million. ${ }^{23}$ The EU was also very

\footnotetext{
15 A. Wittkowsky, 'Squaring the circle: a short history of UNMIK's European Union Pillar, 1999-2008,' Sudosteuropa Mitteilungen, Vol. 49, No. 1, 2009, pp. 16-35.

${ }_{16}$ UNSC, Report of the Secretary-General pursuant to paragraph 10 of Security Council Resolution 1244, 12 June 1999, p.4.

17 J. Dixon, Pillar IV's Role within UNMIK, 1999, <www.seerecon.org>, accessed 15 June, 2008.

${ }^{18}$ I. King and W. Mason, Peace at any Price: How the World Failed Kosovo, London, Hurst \& Company, 2006; USAID, 'Results of Kosova Economic Sector Assessment', 1999 (unpublished report); Wittkowsky, op. cit. One of the reasons for the European Commission's problems in providing funds was that financial procedures had been tightened following the resignation of the previous Commission over financing scandals (S. Fidler, 'Albright irked by Kosovo funds delay,' Financial Times, 28 January 2000).

19 King and Mason, op. cit. and interviews with several former Pillar IV staff in November 2008. USAID had, however, done some preparatory work on economic development needs in Kosovo during the conflict and the speed with which it was able to launch its project suggests there was prior expectation of a US role.

${ }^{20}$ Interviews with Pillar IV advisers who were in Kosovo at that time, conducted in November 2008, with a Ministry of Finance adviser in October 2010.

${ }^{21}$ King and Mason, op. cit..

22 Ibid.

23 UNMIK EU Pillar, EU Pillar Annual Report 2005, 2006; Wittkowsky, op. cit.
} 
slow in fulfilling its other financial commitments to UNMIK. It was not alone in this however, as many donors took considerable time to deliver promised reconstruction project funding and contributions to UNMIK. ${ }^{24}$

Despite these initial operational problems, Pillar IV was able to make significant progress in setting up new government institutions. The EU staff and USAID-funded technical advisers successfully established and managed the Central Fiscal Authority, the Banking and Payments Authority, and administrative departments for Reconstruction, Trade and Industry, and Public Utilities. After the election of a Kosovo government in late 2001, responsibility for most of these functions was progressively handed to the elected Kosovo government. The new taxation and customs regimes established by the Pillar allowed the Kosovo budget to become selffunding within a few years and the World Bank praised the work done in establishing a workable public finance system 'from scratch.'25 Pillar IV's final report, subtitled "Job Done!", identified ten major achievements during the nine years of its existence including establishing the foundations of a market economy, creating a self sustaining Kosovo budget, successful privatisation of state owned enterprises, and modernisation of public utilities. ${ }^{26}$

Several authors have noted that some actions of the EU during this period effectively set Kosovo on the path to independence by establishing relations with Kosovo independent of Serbia. ${ }^{27}$ For example, the EU granted Kosovo 'Autonomous Trade Measures' in December 2000 which created a customs status for Kosovo separate from Serbia. Kosovo was also the first part of post conflict Yugoslavia to formally enter the EU Stabilization and Association Tracking mechanism in November 2002. ${ }^{28}$ However, the first decisive steps were taken well before this when Pillar IV established a budget for Kosovo outside the UN mission's finances and adopted independent economic and monetary policies. Crucial decisions about the use of currency and the new tax and customs systems initiated by Pillar IV effectively separated the administration of Kosovo from the administration of Serbia. By December 2001 the IMF noted that Kosovo's economic policies represented a complete break with the past:

Although a final political settlement for the province is still pending, Kosovo's economic policy today is effectively independent. Indeed in the two and a half years since the end of the conflict, Kosovo has been a laboratory in economic institution building from the ground up. ...The result was an institutional structure that has gone further toward autonomy than originally envisaged.... The outcome is economic policy structures and institutions that are in effect entirely independent. ${ }^{29}$

\footnotetext{
${ }^{24}$ J. Covey, 'Making a Viable Peace: Moderating Political Conflict,' in J.Covey, M. J Dziedzic, and L. Hawley (eds.), The Quest for Viable Peace: International Intervention and Strategies for Conflict Transformation, Washington DC; Arlington, Virginia, United States Institute of Peace Press; Association of the United States Army, 2005, pp. 99-122.

25 World Bank, Kosovo Public Expenditure and Institutional Review, Volume I, 2006.

26 UNMIK EU Pillar, End of Mission Report 1999 - 2008, 2008.

27 Harnisch and Stahl, op. cit.; Klasnja, op. cit.

${ }^{28}$ Klasnja, op. cit.

29 IMF, Kosovo, Progress in Institution-Building and the Economic Policy Challenges Ahead, 2001, p.1-3.
} 
These developments are in strange contrast with the lack of acknowledgement of Kosovo's separation from Serbia in early SAP documentation ${ }^{\circ}$ and current day efforts by EULEX and other EU representatives to remain 'status neutral.' There may not, however, have been any practical alternative to these Pillar IV actions given the administrative needs of Kosovo, and the intransigence of the Serbian government at the time. The final status of Kosovo, or the process for determining it, had not been addressed in UNSCR 1244, and the meaning of the 'substantial autonomy' referred to in the Security Council resolution was open to widely different interpretations. ${ }^{31}$ World Bank and IMF policy advice and USAID technical advisers were influential in setting the policy agenda in the frantic early months of the mission, when EU personnel were still thin on the ground, and they adopted the standard approach to institution building in Kosovo that they would apply in any other post conflict developing country, despite the unique sovereignty issues in Kosovo. It is unlikely, however, that these steps increased the viability of the independence option in final settlement discussions as has been argued. $3^{2}$ The effect is likely to have been marginal given the very strong views of Kosovo's Albanian leaders and the Kosovo Albanian population on the matter.

Eight years after its slow and difficult establishment, the abrupt closure of Pillar IV in mid 2008 was equally confused. In February 2008, after the Kosovo government's declaration of independence, the Commission decided to disband its component of UNMIK, even though UNMIK itself continued to exist under the still operative UNSCR 1244. The decision was somewhat unexpected by the UN, and by Pillar IV staff themselves. There was little advance notice or preparation. The remaining responsibilities of the Pillar were rapidly transferred either to the Kosovo government or to UNMIK with a number of significant issues left unresolved.33

The establishment of the EU's post-independence mission, EULEX, was also to some extent confused and delayed, but in this case most of the delay was due to the reluctance of the Security Council to authorise the withdrawal of UNMIK and the transfer of responsibilities to the EU, and the equal reluctance of UNMIK staff to relinquish their jobs. 34 After much negotiation, the UN Secretary General endorsed the diplomatic fallback of a 'reconfiguration' of the UN presence to allow the EU to take over some of its functions. 35 The EU did, however, again experience problems in the recruitment of staff for the mission, largely due to the number of false starts and delays in deployment. 36

\section{EU reconstruction and development assistance: EAR and ECLO}

The EU has been the largest aid donor in the post conflict period. While many reconstruction assistance projects have had a positive impact, the administration of the EU's aid program has also been criticised for slow implementation, under resourcing, excessive bureaucracy and ineffectiveness. A decision was taken early on

\footnotetext{
${ }^{30}$ Koeth, op. cit.

${ }^{31}$ UN Security Council, United Nations Security Council Resolution 1244, S/RES/1244 (1999), 1999.

${ }^{2}$ Klasnja, op. cit.

33 Wittkowsky, op.cit., and interview with a senior Pillar IV official involved in the closure of the Pillar, conducted by phone in October 2010.

34 H.Dijkstra, 'The Planning and Implementation of the Rule of Law Mission of the European Union in Kosovo', Journal of Intervention and Statebuilding, Vol. 5, No. 2, 2011, pp. 193-210.

35 E. Pond, 'The EU's Test in Kosovo', The Washington Quarterly, Vol. 31, No. 4, 2008, pp. 97-112.

${ }^{36}$ Koeth, op. cit.
} 
that EU aid for Kosovo should be delivered through a specialised agency established for this purpose, rather than through existing EU mechanisms. Like many aspects of the Kosovo exercise, the proposal to establish EAR was a response to the EU's prior experience of coordination problems in implementing reconstruction activities in Bosnia using different sets of procedures under various regulations. EAR was created with the goal of enhancing 'the efficiency, speed and visibility of European assistance', as well as to improve coordination with other donors and avoid duplication of effort. 37 The remit of the agency was subsequently expanded to include other post conflict countries in the region: Serbia and Montenegro after the fall of the Milosevic regime in late 2000; and the Former Yugoslav Republic of Macedonia after the interethnic conflict of 2001.

EAR got off to a faster start than Pillar IV. Within weeks of the end of the conflict, a Kosovo Task Force had arrived and begun the process of disbursing large amounts of funding. The relative speed of the response in relation to EAR was perhaps due to the fact that the EU already had humanitarian assistance projects underway in 1998 and early 1999 before the escalation of the conflict, and thus had staff and contacts to draw on. By September 1999, the Task Force had 30 staff in Pristina and had initiated around $€ 50$ million worth of new reconstruction activities. ${ }^{38}$ Initially, EAR assistance focused heavily on physical infrastructure rehabilitation including housing reconstruction, electricity generation, and de-mining. After the establishment of an elected Kosovo government in 2002, however, more attention was directed to the need for capacity development and institutional strengthening as it became clear that many of the laws, procedures and institutions necessary for effective self government were still lacking. The Agency allocated funding for a succession of projects in various areas of public administration including civil service training, budget preparation, economic planning, public procurement, and audit and financial control.

The possibility of Kosovo's accession to the EU soon became a major influence on EAR activities and its projects explicitly aimed to encourage the adoption of 'EU best practice.' EAR also contributed significant amounts towards helping the Kosovo government to participate in the EU's Stabilisation and Association process, mainly by providing assistance with drafting laws compatible with the EU acquis communautaire. ${ }^{39}$ Around $€ 15$ million has been provided for technical assistance in this field. $4^{\circ}$ EAR was established with an initial mandate of four years which was extended several times. The final mandate expired at the end of 2008 and responsibility for managing EU financial assistance was transferred to the European Commission Liaison Office (ECLO) which continued to follow similar procedures and support similar areas of activity.

Assessments of the impact of specific EU funded projects have largely been positive. An evaluation of capacity building assistance, for example, found that EAR support had been important in the establishment of democratic governance structures and to

\footnotetext{
37 European Commission, Commission Decision of 15 December 1999 Establishing a Programme for the Agency for the Reconstruction of Kosovo, 1999.

38 TAFKO, Monthly Summary of Task Force Activities: July-August 1999, 1999.

39 The body of EU treaties and laws, declarations and resolutions that applicant countries must accept before they can join the EU, <http://europa.eu/abc/eurojargon/index_en.htm>, accessed 9 November, 2011.

40 EAR, <http://ec.europa.eu/enlargement/archives/ear/agency/28-ContractListWeb/kos/kos.htm >, accessed 9 November 2011;

ECLO: <http://eeas.europa.eu/delegations/kosovo/documents/funding_opportunities/contracts_signed_eclo.xl $\mathrm{s} \geq$, accessed 9 November, 2011.
} 
a substantial upgrading of human resources. ${ }^{41}$ However, evaluations of EAR and ECLO activities also identify problems in the planning and implementation of EU projects which have limited their effectiveness and impact. The Independent International Commission on Kosovo, in 2000, for example, pointed to problems due to EU bureaucracy, the duplication of decision-making between Brussels and Pristina, and unwieldy EAR committees prone to micromanagement. ${ }^{2}$ Some of the later criticisms of EU aid implementation relate to the continued use of the projectbased methods initially applied to physical reconstruction projects. As EAR later acknowledged, the project approach was not necessarily appropriate for the 'soft' institutional development activities that became a larger part of the Agency's work and led to 'project cycle thinking' and a fragmented approach which paid more attention to short term project completion at the expense of longer term outcomes. 43 The Agency and subsequently ECLO have found it difficult to escape this way of working, however. As a result, EAR's institution building programs have consisted of a diversity of relatively small technical assistance projects spread across the Kosovo administration. A 2009 evaluation found similar deficiencies in the way activities had been implemented: projects were too ambitious and had too many components, implementation periods were too short, and project indicators were too focused on the delivery of specific outputs rather than longer term outcomes such as capacity and sustainability. 44

Such criticisms of the design and management of EU funded technical assistance activities were repeated in interviews with technical consultants who had been directly involved in EU projects.45 Excessive bureaucracy, delay, and inadequate resources sum up the major complaints. Technical advisers considered that the duration of EU funded projects, normally from 18 months to two years, was insufficient to deliver the expected outputs, and that the time required for project preparation, at least one year, meant that the terms of reference were often out of date by the time the project started. Moreover, there were often large gaps between successive technical assistance projects resulting in 'stop start' development of institutions. Projects were also said to be under-resourced relative to what was required, and funding levels appeared arbitrary, apparently based on a formula of 'one year: one million Euros,'without a clear view of what that sum could actually buy. Reporting requirements were also regarded as onerous, bureaucratic and unproductive, and local EU representatives were considered to lack the technical expertise or authority required to manage the projects effectively. Since 2008, the fact that some EU member states have not recognized Kosovo's independence and the need, therefore, for EU agencies to be 'status neutral' creates further operational difficulties. Documents and reports produced for the Kosovo government by EU

\footnotetext{
${ }^{41}$ European Agency for Reconstruction, Evaluation of the Implementation of Council Regulation 2667/2000 on the European Agency for Reconstruction, Synthesis Report Volume I Part C - Main Evaluation Report, 2004; European Agency for Reconstruction, Executive Summary, Evaluation (EU/11/05/07) Institutional Capacity Building Support (Kosovo), 2008.

${ }^{42}$ Independent International Commission on Kosovo, Kosovo Report: Conflict, International Response, Lessons Learned, Oxford, Oxford University Press, 2000 (Published to Oxford Scholarship Online: November 2003 DOI: 10.1093/0199243093.001.0001).

43 European Agency for Reconstruction, Annual Report to the European Parliament and the Council, January to December 2004, 2005; European Agency for Reconstruction, Executive Summary, Evaluation (EU/11/05/07) Institutional Capacity Building Support (Kosovo), op. cit.

44 European Commission, Retrospective Evaluation of the CARDS Programmes: Kosovo, Final Evaluation Report, 2009.

45 Interviews conducted in October 2010 with four international and two local consultants engaged in implementing EU technical assistance.
} 
funded advisers are not able to mention the Republic of Kosovo or use government symbols. This generates tension with senior government officials and has sometimes resulted in the government rejecting EU funding. ${ }^{46}$

There is evidence that the EU has taken note of some of these criticisms. The 2009 annual report on activities funded under the Instrument of Pre Accession (IPA) noted that steps are being taken to improve IPA effectiveness by moving towards a sectorbased approach to planning and by enhancing donor coordination and increasing beneficiary ownership. This follows earlier streamlining of IPA processes in 2009 with fewer, larger projects to make implementation easier to manage and to increase both effectiveness and visibility of EU funding. 47

\section{Appropriateness of EU policy priorities and assistance programs}

The EU's strategy in the Western Balkans is to offer the benefits of EU 'integration' and the prospect of eventual membership in exchange for compliance with EU requirements and 'European standards.' The EU thus treats Kosovo as an accession candidate rather than as a developing country. However, Kosovo has serious economic problems, an estimated unemployment rate of 40 per cent, significant poverty, low education and health care standards, and a high level of corruption..$^{8}$ It is not clear that requiring Kosovo to comply with the demanding criteria for EU membership is a realistic way to address these challenges at the current time. Moreover, many of the requirements of EU conditionality appear to be designed more to benefit the EU and its membership than to address the priorities of Kosovo. In particular, it has been argued that EU policy priorities do not align with issues regarded as important by the government or the people of Kosovo. 49

The 'Stabilization and Association' process for the countries of South East Europe, initiated in 1999 by the European Commission, offers benefits in the form of access to the EU market and financial assistance as incentives to support the institutional

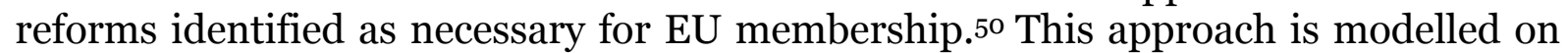
the successful strategy adopted towards transition economies in Central and Eastern Europe in the 1990s. The conditions that potential members need to comply with include the 'Copenhagen criteria' which require a candidate country to have stable democratic institutions, a functioning market economy, and the ability to assume the obligations of membership. A candidate country must also have translated EU legislation into national legislation and show that it is implemented and enforced

\footnotetext{
${ }^{46}$ Interview with an EU funded international technical adviser, October 2010.

47 European Commission, 2009 Annual Report on the Implementation of the Instrument for Pre-Accession Assistance (IPA) SEC(2010) 1430, 2010, <http://ec.europa.eu/enlargement/press_corner/keydocuments/cards_reports_and_publications_en.htm\#5>, accessed 19 August 2011.

48 World Bank, Kosovo: Unlocking Growth Potential: Strategies, Policies, Actions. A Country Economic Memorandum, 2010; European Commission, Kosovo 2011 Progress Report, SEC(2011) 1207, Brussels, 12 October 2011.

${ }^{49}$ S. Keukeleire, A. Kalaja, and A. Çollaku, 'The EU and Kosovo: Structural Diplomacy in Action - but on the Basis of One-Sided Paradigms?,' Policy Paper 4, The Diplomatic System of the European Union, Jean Monnet Multilateral Research Network, February 2011,

<http://dseu.lboro.ac.uk/Documents/Policy_Papers/DSEU_Policy_Papero4.pdf>, accessed 20 April 2012.

$5^{\circ}$ European Commission, Commission proposes a Stabilisation and Association process for countries of SouthEastern Europe (Press Release), IP/99/350, Brussels, 26 May 1999; <http://ec.europa.eu/enlargement/thepolicy/countries-on-the-road-to-membership/index_en.htm>, accessed 15 August 2011;

<http://ec.europa.eu/enlargement/how-does-it-work/index_en.htm>, accessed 9 November, 2011.
} 
effectively through the appropriate administrative and judicial structures. ${ }^{51}$ In 1999 Kosovo was clearly a long way from being able to meet these requirements, but once the initial post conflict phase was over, the activities of the EU in Kosovo, as well as those of many bilateral donors, were increasingly influenced by the prospect of Kosovo one day joining the EU. Since 2005, the European Commission has published annual reports assessing Kosovo's progress towards conforming with accession requirements. $5^{2}$

While the EU's objective of security and stability in the region, and broad aspirations for improvements in the rule of law, media freedom, regional cooperation and economic development are worthy long term goals, 53 it can be questioned whether incorporating 'EU standards' into national legislation and policy is the most appropriate means for achieving these ends. Implementing the criteria for $\mathrm{EU}$ membership requires a high level of state capacity that CEE countries were able to deliver but that Kosovo at present does not possess. The annual Progress Reports of the European Commission track Kosovo's status on an extensive array of issues, from the procedures of the Assembly and the conduct of elections to policies on health and safety at work, transport, food standards, nuclear safety, climate change and everything in between. Advancement in all these areas appears to be equally necessary for Kosovo to achieve its "European perspective".54 There is rarely in EU documents, however, an explicit argument that the reforms recommended will themselves significantly improve Kosovo's economic situation. The purpose of 'approximation to European standards' is to qualify Kosovo for closer trade relations with the EU, which would then be expected to bring economic benefits.55 However, Kosovo's economic underdevelopment and consequent weak state capacity mean that it faces significantly greater challenges in meeting the standards for enlargement.56 International advisers working on institutional development in Kosovo are quite pessimistic about the likelihood that Kosovo's current deficiencies can be addressed sufficiently to meet the requirements of membership in the foreseeable future. ${ }^{57}$ In addition, factors external to Kosovo referred to earlier, including the recognition issues, raise doubts about the likelihood of Kosovo achieving the benefits of closer relations with the EU in the near term. EU integration thus appears to be a very roundabout and demanding way to achieve economic progress.

Furthermore, when it comes to providing financial and technical support for institutional reforms, it can be argued that the EU's assistance programs and policy priorities in Kosovo focus more on issues of concern to EU members than on Kosovo's economic development. EU financial assistance under the Instrument of Pre Accession Assistance (IPA) is oriented around the accession criteria and addressing the shortcomings set out in the annual SAP progress reports. Keukeleire et al. argue that, as a consequence, the EU has provided limited assistance under the IPA in the

\footnotetext{
51<http://ec.europa.eu/enlargement/the-policy/conditions-for-enlargement/index_en.htm>, accessed 15 August 2011.

$5^{2}<$ http://ec.europa.eu/enlargement/how-does-it-work/progress_reports/index_en.htm>, accessed 13 October, 2011.

53 European Commission, Enlargement Strategy and Main Challenges 2011-2012, COM (2011) 666, Brussels, 12 October 2011.

54 European Commission, Kosovo 2011 Progress Report, op.cit.

55 European Commission, Kosovo - Fulfilling Its European Perspective, COM(2009) 5343, Brussels, 14 October 2009.

${ }^{6}$ Keukeleire, Kalaja, and Çollaku, op.cit.

57Interviews with several international technical advisers engaged on EU projects in Pristina conducted in September and October 2010.
} 
areas of labour, education and health, even though unemployment, limited human resources and an inadequate education system have been identified as Kosovo's major current problems. $5^{8}$

Certainly, almost 40 per cent of IPA funds approved in 2010 were allocated to projects to support the 'political criteria' for EU accession and are being used, among other things, to promote law and order, reduce people trafficking, combat organised crime, improve police intelligence and counter money laundering, corruption and the financing of terrorism: activities with significant flow on benefits to EU Member States. A further 10 per cent of funds will provide general technical assistance to the Ministry of European Integration for its work in pursuing the EU accession criteria. Nevertheless, the program does include significant economic development initiatives. Thirty per cent of 2010 IPA funds are earmarked for regional economic development and agriculture development under the umbrella of the 'Economic Criteria,' and further projects addressing the 'European Standards' criteria in food production, energy regulation and water management may also have economic benefits to the extent that they facilitate exports and investment.59 Figure 1 shows the distribution of 2010 IPA funds between major activity areas.

\section{Figure 1: Distribution of 2010 IPA funds for Kosovo}

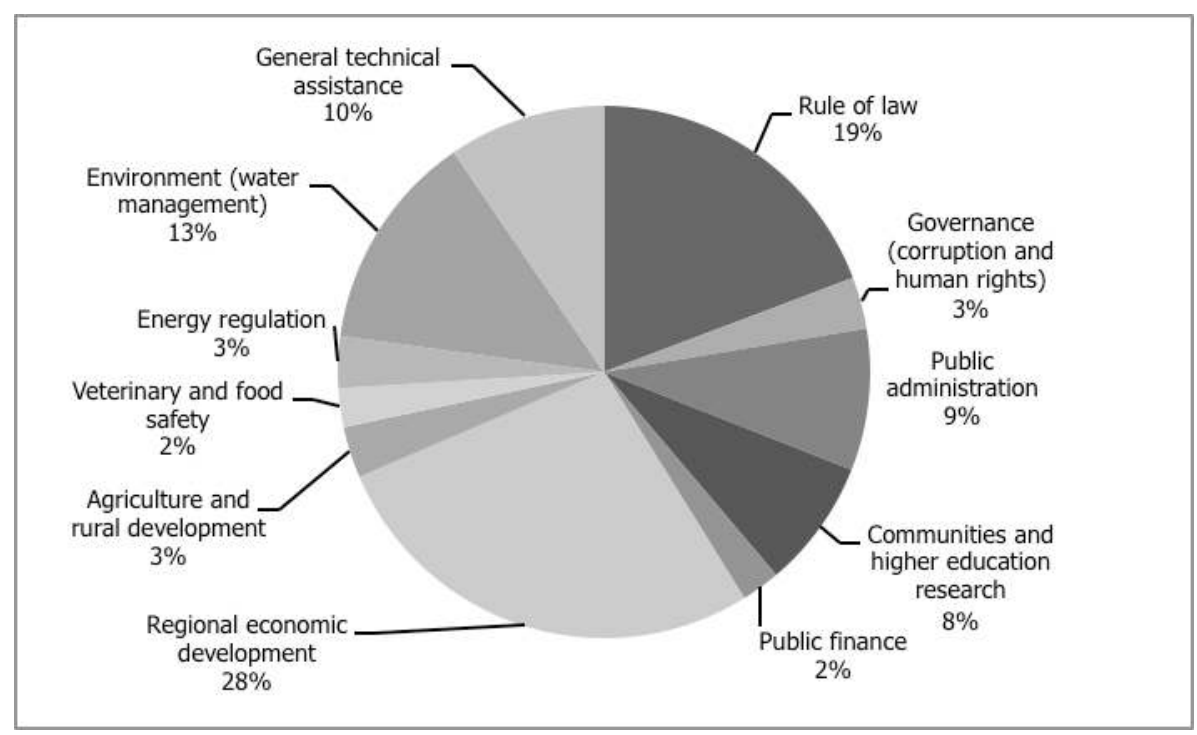

In some areas of EU assistance, the attention focused on implementing the acquis perfectly has produced a tendency to apply rigid frameworks and to focus on the formal aspects of developing EU compliant legislation, rather than ensuring its effective implementation to achieve positive economic and social outcomes. The EU has, for example, provided considerable support to the development of public procurement policy and Kosovo's procurement law has now been revised three times in six years in efforts to align it with the EU model. However, actual implementation

\footnotetext{
$5^{8}$ Keukeleire, Kalaja, and Çollaku, op.cit.

59 European Commission, Commission Decision Adopting an Annual Programme for Kosovo under the IPA

Transition Assistance and Institution Building Component for 2010, C(2010) 9402, Brussels, 17 December 2010.
} 
of procurement processes continues to be subject to serious problems of corruption, inefficiency and waste. ${ }^{60}$

Moreover, many of the EU's preferred administrative policies are highly complex and not necessarily appropriate for an economically underdeveloped country with limited administrative capacity such as Kosovo. EU policies are often either 'least worst' solutions negotiated over the years between EU member states, or bright theoretical ideas generated in Brussels. Some advisers working on public finance issues argued, for example, that EU procurement law is considered excessively complex compared to some other models and difficult to implement efficiently, and that the EU Value Added Tax (VAT) system is not what would be recommended to a developing country if EU alignment was not an issue. ${ }^{61}$ In many of the areas covered by the accession criteria, there is no single agreed EU framework, and sometimes marked differences in practices between the various EU Member States, causing confusion for government officials attempting to 'approximate' EU standards, and conflicts between technical advisers from different parts of Europe over which national approach should be applied as the 'EU standard' in Kosovo.62 Indeed, some of the policy frameworks being promoted by EU advisers have apparently been invented specifically for application in potential member countries. ${ }^{63}$

This last point raises the question of 'ownership' of institutional reforms and development programs under the regime of supervision and conditionality imposed by the EU. The reforms that must be implemented by the Kosovo authorities are defined by the EU, and in many cases the precise details of how they should be dealt with in national legislation and procedures are also set out in EU regulations. This approach appears completely at odds with the commitments made by aid donors, including EU members, in other contexts to the importance of national 'ownership' of reform programs and the need to align assistance programs with national development plans. ${ }^{64}$ As in many other assistance programs in developing countries, 'ownership' in reality simply means 'compliance.'

\section{Conclusion}

The EU had high ambitions in Kosovo but it lost significant ground right at the start of its involvement when the Commission, having committed itself to participate in the UN mission, was unable to mobilize sufficient financial resources or staff quickly enough to fulfil its promises. It took several years to recover from this delay. EAR performed better in the early period but the EU's management of institutional development and technical assistance activities has been criticised by both local and international observers. Resources appear to have been dissipated in multiple, short term, under-resourced projects, increasing the transaction costs for both the EU and

\footnotetext{
60 Office of the Auditor General, Annual Audit Report on the Financial Year 2010, Pristina, Republic of Kosovo, Office of the Auditor General, 2011, and interviews with procurement specialists (two international and one national) in Pristina in October 2010.

${ }^{61}$ Based on interviews with several international technical advisers with experience in these sectors, conducted in Pristina in October 2010.

62 Reported in interviews with several international advisers and local consultants in Pristina in October 2010. 63 The EU-recommended 'Public Internal Financial Control (PIFC)' approach to public finance management issues, for example, according to the consultants engaged by the EU to implement it, is unknown in the 'old' EU Member States, or most other developed economies (interviews with two internal audit advisers in September and October 2010).

64 OECD, Paris Declaration on Aid Effectiveness, Paris, OECD, 2005.
} 
the government and resulting in 'stop start' development of institutions. It can be argued moreover that the EU's approach, which rests on the idea of applying 'EU standards,' is not appropriate for a country like Kosovo which is still a long way from being able to meet these requirements. EU legislation and policies are not necessarily international best practice models, and imposing them on a developing country that has no near term prospect of joining the EU may divert attention and resources from more immediately relevant reforms. It also creates the possibility that EU conditionality will simply produce the appearance of compliance without real commitment to reform or good government. 